\title{
A Note on the Chemical Composition and Origin of Peridot from the Harrat Kishb, Saudi Arabia
}

\author{
Adel A. Surour \\ Geology Department, Faculty of Science, Cairo University, 12613 Giza, Egypt \\ Email: adelsurour@hotmail.com
}

\begin{abstract}
Zabarjad (peridot in Arabic) is a common gemstone of valuable importance used in jewelry. It is the mineral olivine that has some gemological characters that classify it as peridot or gem olivine. Although it is not found in huge quantities in Saudi Arabia, there are some mining activities to extract peridot from the Harrat Kishb where the mineral is found scattered in alkali basalt or in the scree and wadi deposits. The basaltic flows at the Harrat Kishb include this gem olivine in the form of mantle xenoliths that comprise both dunite and peridotite. The size of collected peridot lies in the range of 0.4-0.8 cm and it occurs either as free olivine or in the form of cluster with components of host basalt. The collected crystals are transparent olive-green after washing and screening. Using the modern technique of analysis by the electron microprobe, the accurate chemical composition of peridot crystals was obtained. The studied peridot is a Mg-rich end-member of the foresterite $(\mathrm{Mg})$ and fayalite $(\mathrm{Fe})$ solid solution series where the forsterite content is $\mathrm{Fo}_{90.35-92.31}$. Such composition of olivine is similar to majority of olivine in the ultramafic mantle beneath the western Arabian Peninsula. The present work uses the concentrations of some elements such as $\mathrm{Mn}, \mathrm{Ni}$ and $\mathrm{Ca}$ in addition to the forsterite content to characterize the Saudi peridot. It is typically terrsterial when compared to extraterrestrial (pallastic) olivine, and mostly xenocrystic and rarely magmatic. The forsterite content $\left(\mathrm{Fo}_{>90}\right)$ suggests transition from a residual to cumulate origin.
\end{abstract}

Keywords: Peridot; Harrat Kishb; xenocryst; peridotite nodules; residual melt

\section{Introduction}

Peridot (gem-olivine) is a common mineral in mafic and ultramafic rocks, and is often found in lavas and in peridotite xenoliths of the mantle that lavas carry to the surface. "Zabargad" or "Zabarjad" are the Arabic name for gem quality olivine (Wise, 2016). The Romans mined the Egyptian peridot as early as 1500 B.C., and they sometimes called it "evening emerald" for its olive tinge and more subtle hue. The Zabargad (St. John's) Isle off the Egyptian Red Sea coast is the type locality of best quality peridot in ancient times but some historic sites were known in Myanmar as well (Shigley et al., 2000). A new deposit in the Himalayan Mountains (Pakistan) was discovered in 1994 that producing the finest peridot in the world now. As to quantity, about 80-95\% of the world's production comes from the San Carlos Apache Indian Reservation in Arizona, USA (USGS, 2016, Hadnott et al., 2017). Some volcanoes in Hawaii are source of "olivine sands", which are composed of transparent green grains of peridot at the foot-slope of the volcanic mountains, and the peridot there is called "Pele's tears" by the native Hawaiians.

Beside its common occurrence in mafic-ultramafic rocks, peridot occasionally occurs in thermally metamorphosed impure carbonate sediments such as dolomite and dolomitic limestone. There is an extraterrestrial or "pallastic" peridot, and in this context olivine is the only gemstone found in meteorites. In this respect, the Fukang meteorite is a relatively recent pallastic find in 2000 that was discovered in Xinjiang Yugar province, China (Lauretta et al., 2006). It contains the so-called "space gems" and it is believed to have the same age of the solar system ( $\sim 4.5$ billion years). It is known that peridot is the anniversary gemstone for the $16^{\text {th }}$ year of marriage.

The present work represents the first mineralogical note about the chemistry and genesis of peridot in the volcanic field of the Harrat Rahat in central West Saudi Arabia. There is a need to characterize the Saudi peridot minerallogically, and the present study focuses on the picked crystals that are mined on a local scale, then polished and available on board of the Saudi Airlines and grand malls in most. 


\section{Geologic Setting and Mode of Occurrence}

The volcanic fields in the western part of the Arabian Peninsula $\left(180,000 \mathrm{~km}^{2}\right)$ are represented by the so-called "harrats" (Fig. 1) that are related to the Oligo-Miocene rift system of the Red Sea (Brown et al., 1963; Kuo and Essene, 1986). They include a wide variety of voluminous basaltic flows, much lesser silicic pyroclastics, flows and plugs, in addition to a common occurrence of volcanic cones and peculiar craters. The Harrat Kishb (sometimes pronounced as Al-Kishb) lies in a very famous geologic feature, which is the N-S trending Makkah-Madinah-Nufud (MMN) volcanic line that extends for $\sim 600 \mathrm{~km}$ (Robool and Camp, 1991). They (op. cit.) considered that the majority of the harrats are defined by a 30-20 Ma zone of continental rifting followed by a new fracture system during the last 10 Ma that operates independently from the Red sea rift. Salf and Shah (1988) believed that volcanic activity started 10-14 Ma ago, and took place from long fissures in areas characterized by grabens, fault scarps and fractures. In general, the tectonic model for the formation of the Saudi Harrats is still a matter of dispute. Moufti et al. (2012) and Murcia et al. (2013) believed that the volcanic fields are situated above a thinned lithosphere beneath the Makkah-Medinah-Nafud volcanic line. They (op. cit.) are in favor of involvement of a continental lithosphere rather than a young or fossil plume, and the volcanism took place in east-west extensional thinning of the lithosphere and consequent melting of upwelling asthenosphere. Earlier works (e.g. Thornber, 1992) suggested magma generation from a volatile-rich metasomatic melt formed by small degree $(\sim 5 \%)$ partial melting of mantle near the lithosphereasthenosphere boundary. Recently, Konrad et al. (2016) used He isotopes and trace elements to consider volcanism in western Saudi Arabia as being formed by admixing of ancient enriched lithospheric mantle and shallow depleted mantle asthenosphere.

The Harrat Kishb is $\sim 2.5 \mathrm{Ma}$ (i.e. Pleistocene) and possible younger ages (Holocene to Recent) at the northern boundary of Sahl Rakbah and lies east of Harrat Lahat (Brown et al., 1963; Coleman et al., 1983). There, the basaltic lava was extruded on a Precambrian peneplain forming a barrier to northward drainage from the Sahl Rakbah. At the southwestern extreme of the Harrat Kishb, an inferred maar crater (Al Wahbah, Fig. 2) with perfect, complex and well preserved geological features that made Moufti et al. (2013) considered it as a prominent geopark. Sahl and Smith (1986) recognized three formations at the harrat Kishb especially in its southern part, namely the Unayyizah Formation (Tertiary-Quaternary), the Waabah and Hil formations of Quaternary age. Roobol and Camp (1991) stated that the volcanic rocks at the Harrat Kishb are distinguished into three major units, from oldest to youngest, as the Diakah, and Nafrat units (Pleistocene) and the Hil basalts (Holocene) as shown in Fig. 2. The Diakah unit is the most voluminous and it consists mainly of alkali olivine basalt with much lesser amounts of hawaiite and phonotephrite. According to Roobol and Camp (1991) the youngest Hil basalts can be further subdivided into six sub-units in which the youngest one comprises the products of three eruptions during the Holocene that led to the development of scoria cones, basaltic flows and finally thick phonolite domes like those at the Jabal Shalman.

As to the mode of occurrence, our field observations confirm that peridot in the volcanic rocks of the Harrat Kishb is confined to the youngest scoria cones and some peridotite nodules or xenoliths. The department of gemstones at the Saudi Geological Survey estimated $\sim 7,000 \mathrm{~kg}$ of gem-quality peridot in a nearly seven feet thick debris at the foot-slope of the scoria cones with variation in quantity and quality. Earlier investigations (e.g. Collenette and Grainger, 1994) showed that the Kishb peridot crystals are found loose in scree around scoria cones at three main, and several lesser, localities (Fig. 2). Our field observations recorded some peridotite nodules with up to $1.2 \mathrm{~cm}$ long peridot crystals, in addition to the xenocrysts in the host basalt. Figure 3 shows the collected xenocrysts from the scoria debris before and after screening and washing. 


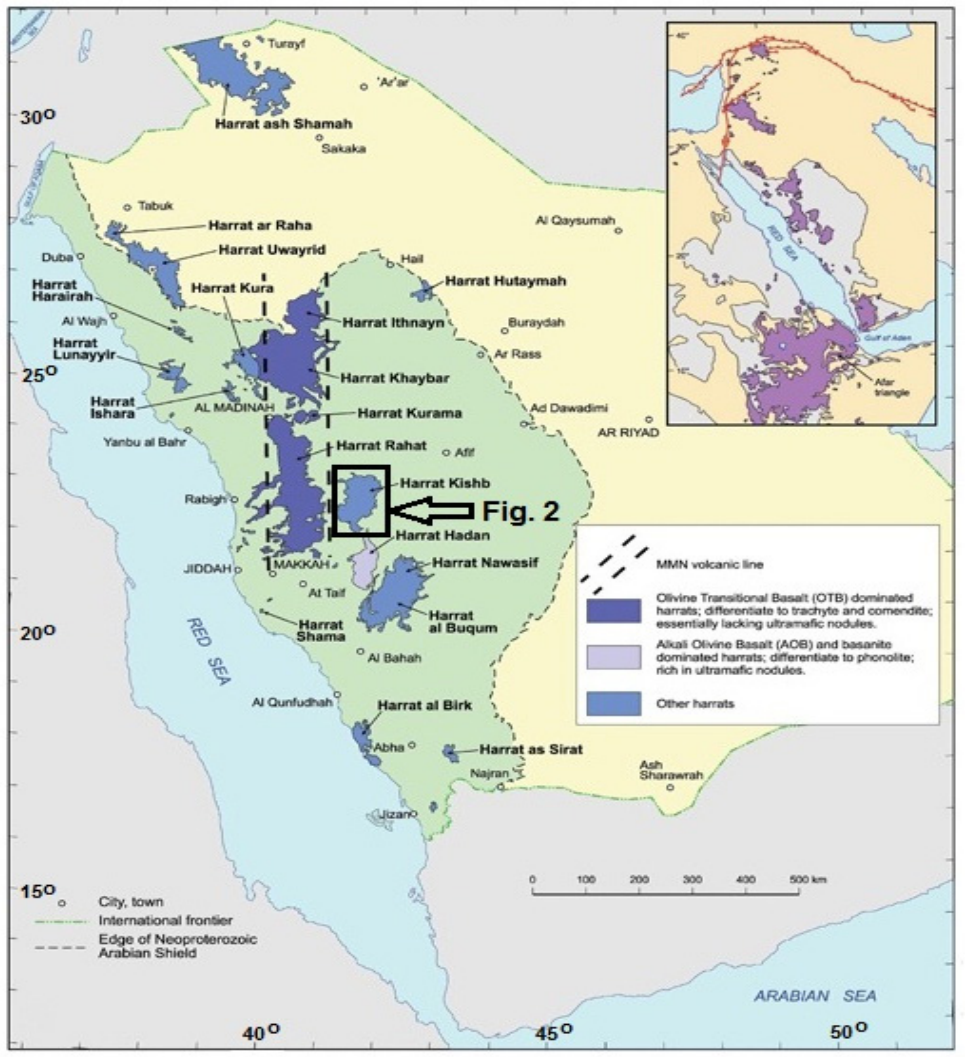

Figure 1. Distribution of the volcanic fields (harrats) in western Saudi Arabia and location of the Harrat Kishb shown in Fig. 2. The inset map shows the regional distribution of rift-related volcanic in the Arabian Peninsula and northeast Africa.

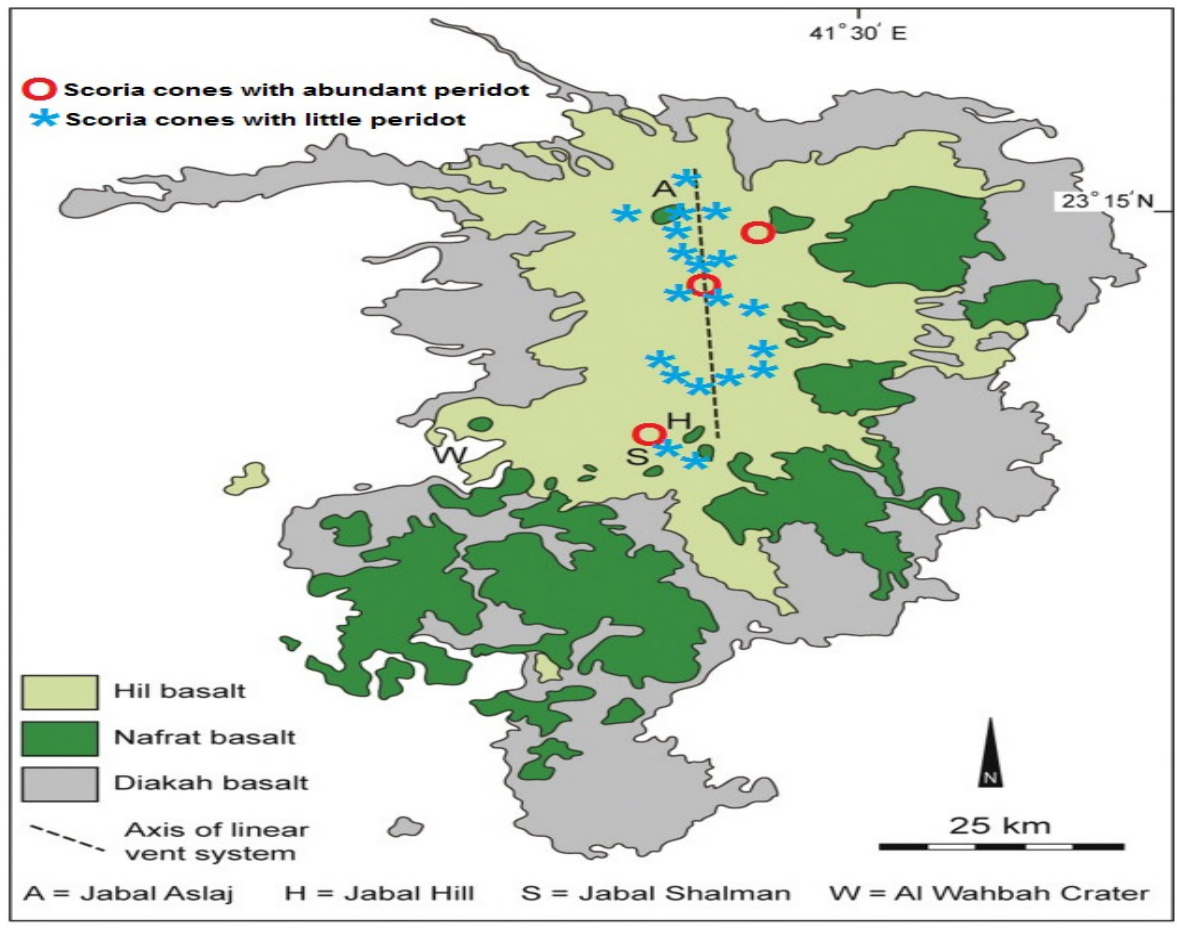

Figure 2. Detailed geological map of the Harrat Kishb (modified by Ahmed et al., 2016 after Roobol and Camp, 1991). The locations of peridot bearing scoria cones of the Hil Formation are given (Collenette and Grainger, 1994). 

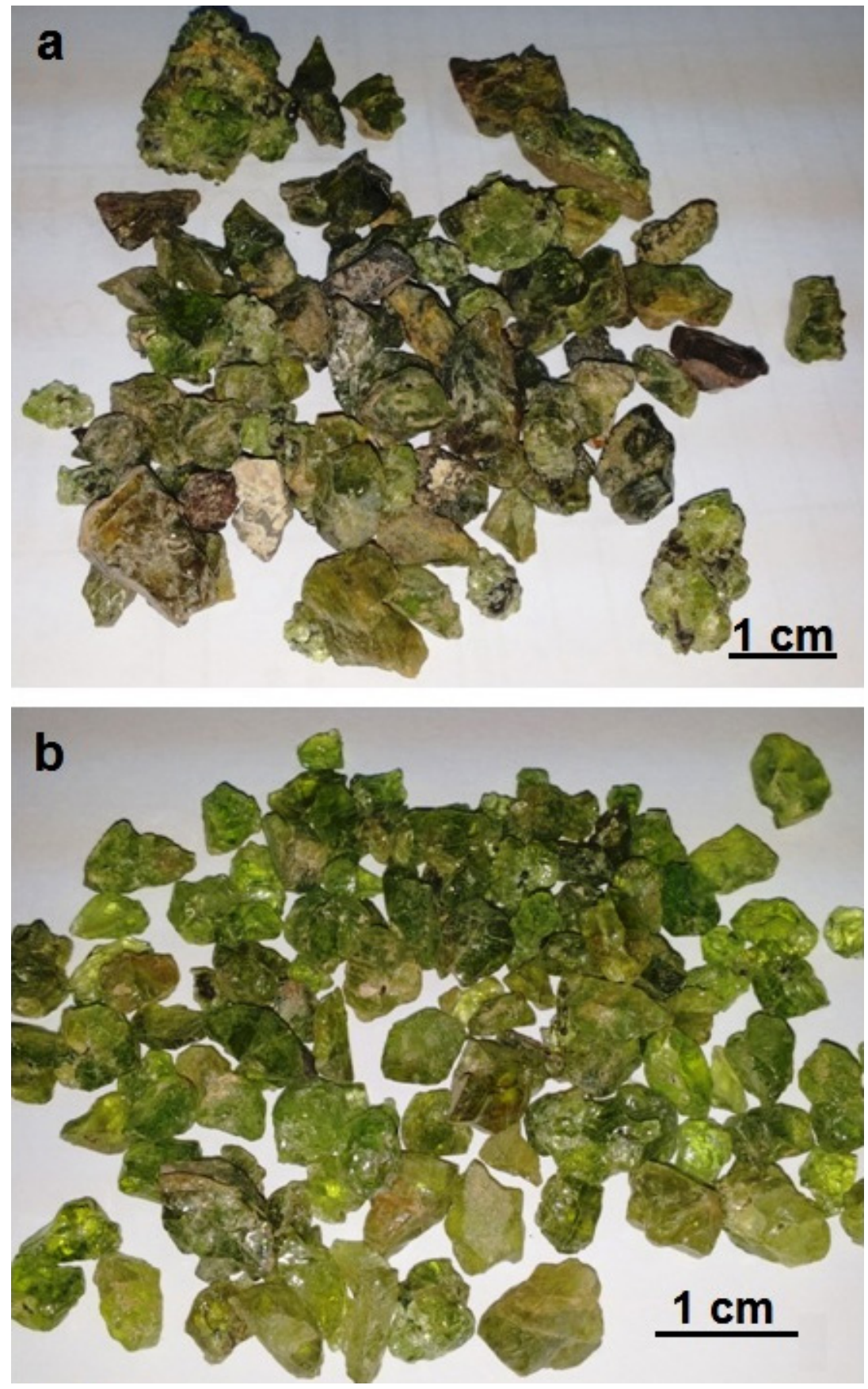

Figure 3. Raw peridot from the Harrat Kishb picked up from the scree at the foot-slope of scoria cones before and after screening and washing for the purpose of purification ( $\mathrm{a}$ b, respectively).

\section{Methodology and Chemical Composition}

The quantitative electron microprobe (EPM) analyses were conducted using a Jeol JXA8200 instrument housed at the Faculty of Earth Sciences, King Abdulaziz University, Jeddah, Saudi Arabia. Operating conditions were $15 \mathrm{kV}$ accelerating voltage, $20 \mathrm{nA}$ probe current, $3 \mu \mathrm{m}$ beam diameter and 15-20 counting time per element. The following standards were used: quartz for Si, eskolaite for Cr (99.99 wt\% $\mathrm{Cr}_{2} \mathrm{O}_{3}$ ), periclase for $\mathrm{Mg}$, wollastonite for $\mathrm{Ca}$, fayalite for $\mathrm{Fe}$, corundum for $\mathrm{Al}$, nickel oxide for Ni (99.99 wt\% $\mathrm{NiO}$ ), $\mathrm{KTiPO}_{5}$ for $\mathrm{K} \& \mathrm{Ti}$, jadeite for $\mathrm{Na}$ and manganosite for Mn. The EMP analyses of six gem olivine crystals from the Harrat Kishb are given in Table 1. 
Table 1. Electron microprobe analyses of the Saudi peridot

\begin{tabular}{ccccccc}
\hline Crystal No. & KB-1 & KB-2 & KB-3 & KB-4 & KB-5 & KB-6 \\
\hline $\mathrm{SiO}_{2}$ & 40.74 & 40.8 & 41.38 & 41.19 & 41.98 & 41.39 \\
$\mathrm{TiO}_{2}$ & 0 & 0 & 0.01 & 0 & 0 & 0.02 \\
$\mathrm{Al}_{2} \mathrm{O}_{3}$ & 0.02 & 0.02 & 0.02 & 0 & 0 & 0.01 \\
$\mathrm{Cr}_{2} \mathrm{O}_{3}$ & 0 & 0.02 & 0.02 & 0.05 & 0.05 & 0 \\
$\mathrm{FeO}$ & 8.69 & 8.69 & 9.19 & 7.48 & 7.63 & 9.39 \\
$\mathrm{MnO}$ & 0 & 0 & 0 & 0 & 0 & 0 \\
$\mathrm{MgO}$ & 49.65 & 49.57 & 49.43 & 50.46 & 50.79 & 49.57 \\
$\mathrm{CaO}$ & 0.03 & 0.03 & 0.02 & 0.01 & 0.2 & 0.04 \\
$\mathrm{Total}$ & 99.13 & 99.13 & 100.07 & 99.19 & 100.65 & 100.42
\end{tabular}

Cations calculated on the basis of 4 oxygen atoms

\begin{tabular}{ccccccc}
$\mathrm{Si}$ & 1.001 & 1.003 & 1.011 & 1.007 & 1.013 & 1.008 \\
$\mathrm{Ti}$ & 0 & 0 & 0 & 0 & 0 & 0 \\
$\mathrm{Al}$ & 0.001 & 0.001 & 0.001 & 0 & 0 & 0 \\
$\mathrm{Cr}$ & 0 & 0 & 0 & 0.001 & 0.001 & 0 \\
$\mathrm{Fe}^{2+}$ & 0.179 & 0.179 & 0.188 & 0.153 & 0.154 & 0.191 \\
$\mathrm{Mn}$ & 0 & 0 & 0 & 0 & 0 & 0 \\
$\mathrm{Mg}$ & 1.819 & 1.817 & 1.800 & 1.839 & 1.827 & 1.799 \\
$\mathrm{Ca}$ & 0.001 & 0.001 & 0.001 & 0 & 0.005 & 0.001 \\
$\Sigma$ cations & 3 & 3 & 3 & 3 & 3 & 3 \\
$\Sigma$ oxygen & 4.001 & 4.003 & 4.011 & 4.007 & 4.013 & 4.008 \\
End members & $($ Mole $\%)$ & & & & & \\
Tephorite & 0 & 0 & 0 & 0 & 0 & 0 \\
Forsterite & 91.02 & 91.01 & 90.53 & 92.31 & 91.99 & 90.35 \\
Fayalite & 8.94 & 8.95 & 9.44 & 7.68 & 7.75 & 9.60 \\
Ca-Olivine & 0.04 & 0.04 & 0.03 & 0.01 & 0.26 & 0.05 \\
& & & & & & \\
NiO & 0.38 & 0.31 & 0.38 & 0.31 & 0.28 & 0.35 \\
\hline
\end{tabular}

The obtained EMPA of the Kishb peridot have very characteristic trace elemt chemical composition, particularly $\mathrm{Mn}$ and $\mathrm{Ni}$. The binary plot of $\mathrm{MnO}$ vs. $\mathrm{NiO}$ of the analyzed crystals decides very distinctly that they are terrestrial and not pallastic olivine (Fig. 4a). It is evident that $\mathrm{Mn}$ cations are totally absent and $\mathrm{NiO}$ content is in considerable amount that ranges from 0.28 to 0.38 wt \% (Table 1). According to Shen et al. (2011), other trace elements such as Zn, Co, V and Li are very helpful to distinguish terrestrial from pallastic olivine. In the present study, we obtained a forsterite content $\left(\mathrm{Fo}_{90.35-92.31}\right)$ is calculated from the EMPA. Forsterite content $=100 \mathrm{Mg} /\left(\mathrm{Mg}+\mathrm{Fe}^{2+}\right)$ where $\mathrm{Mg}$ and $\mathrm{Fe}$ represent molar proportions. The plots of Fo vs. CaO (Fig. 4b) suggest that the Kishb peridot is xenocrystic and only a single crystal probably represents a magmatic phenocryst from the host basalt.

Olivine Fo versus $\mathrm{NiO}$ content distinguishes two types of ultramafic mantle xenoliths (Fig. 4c). Type $\mathrm{I}=$ residual harzburgites, Type II = magmatic or cumulus xenoliths. The nominal mantle value of olivine in equilibrium with the parent mantle is $\mathrm{Fo}_{91}$, given by the vertical line. This is more magnesian than any known magmatic xenolith, and not as magnesian as the typical or average olivine in residual harzburgite. 

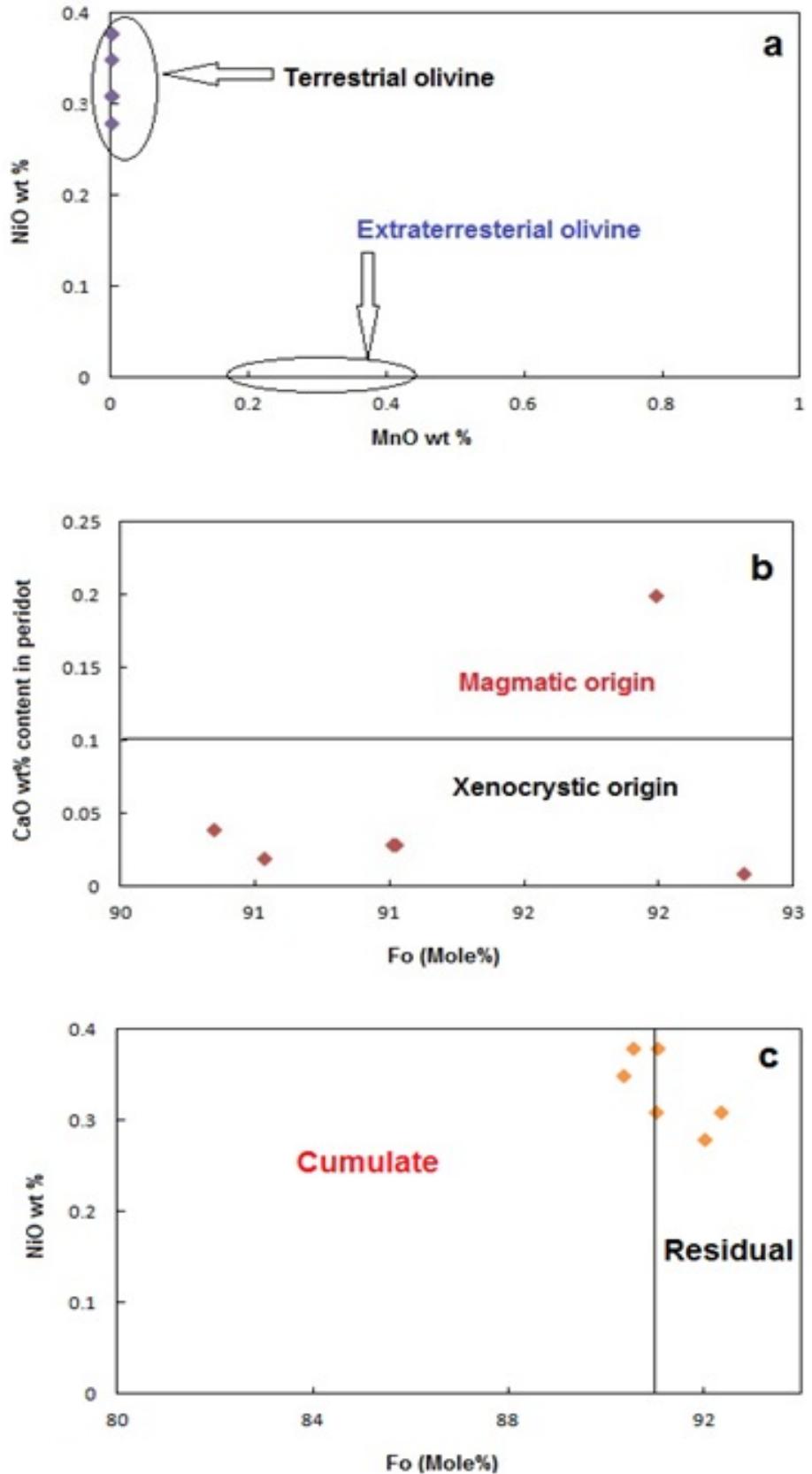

Figure 4. (a) Plots of the Kishb peridot in the field of terrestrial olivine on the diagram of Shen et al. (2011); (b) Xenocrystic origin of most the Kishb peridot crystals on the diagram of Gao et al. (2008); (c) Gradation of the Kishb peridot from residual to cumulate olivine on the diagram of Natland (2009).

\section{$4 \quad$ Discussion and Conclusion}

Most accepted model for the Harrat Kishb volcanics is suggested by Camp and Roobol (1992); Moufti et al. (2012) and Murcia et al. (2013) who preferred mantle upwelling and magma generation by partial melting from the asthenosphere. This is opposite to some models for peridot of the Egyptian Zabargad Isle that believe in large scale plume-lithosphere interaction for the magma generation (Hop et al., 2004). The estimated $P$-T estimates of the peridote-rich peridotite from the Harrat Kishb are (9-16 kbar) and $\left(877-1227^{\circ} \mathrm{C}\right.$ ), respectively (Ahmed et al., 2016) who suggested formation conditions similar to most sub-arc abyssal-type peridotites elsewhere in the world. The Kishb peridot is confined to the scoria cones of the Hil Formation only that are related to the youngest volcanic event with ${ }^{40} \mathrm{Ar} /{ }^{39} \mathrm{Ar}$ age of $1.178 \pm$ 
0.007 Ma (Abdel Wahab et al., 2014) or even younger as 4,500 to 2,000 yr B.P. (Based on K-Ar ages; Camp et al., 1992), i.e. prehistoric.

On a field basis, the ultramafic nodules are believed to be the main source of the loose peridot, but a considerable amount of xenocrysts are found in the scoria of the associated basaltic flows. The peridot of Harrat Kishb is transparent with clear olive-green colour that makes it a precious and valuable gemstone for usage in jewelry. The washed and screened crystals appear very attractive and become ready for installment in rings, necklaces and whatsoever. Using the concentrations of some elements ( such as $\mathrm{Mn}, \mathrm{Ni}$ and $\mathrm{Ca}$ ) characterize the Saudi peridot. Generally, $\mathrm{Ca}$ is a major cation but it is commonly reported in trace amounts in the structure of olivine. The Saudi peridot is typically terrsterial olivine if compared with extraterrestrial (pallastic) olivine. Most of peridot is xenocrystic and rarely magmatic in origin. The few recorded magmatic crystals represent phenocrysts from the host alkaline basalt. Nevertheless, the investigated Kishb peridot might form by a similar way to chonderites with chondrules of gem olivine that result from a residual melt in which there is a remarkable increase in the content of incompatible elements (Rubin and Ma, 2017).

Forsterite content of the Kishb peridot is in the range of 90.35-92.31 mole \% indicating that differentiation begins in the mantle and does not proceed to shallow levels except for few cases. Similarly, Ahmed et al. (2016) analyzed olivine $\left(\mathrm{Fo}_{90-92}\right)$ from the peridotite mantle xenoliths in the Kishb basaltic rocks. According to Natland (2009), forsterite content less than 88 mole $\%$ is an indication of differentiation extension to shallow levels. Natland (op. cit) considered the forsterite content $\left(\mathrm{FO}_{91}\right)$ of olivine as useful distinction between residual and cumulate xenoliths, namely type I and II, respectively. Type 1 is residual xenoliths, representing material, mainly harzburgite, from which basalt was extracted at some extent. On the other hand, Type II is a high-P magmatic segregation or cumulates, chiefly belonging to a series comprising dunite, wehrlite, clinopyroxenite and rare harzburgite. The clinopyroxene is green, not pink or brown, so it is not titanaugite like that in the host basalt. This composition of olivine in the xenoliths is similar to that in the ultramafic mantle that underlies Arabian Peninsula in its western part. The Harrat Kishb alkaline rocks (that host peridot) probably formed by fractional crystallization is static high-level magma chamber with primary enrichment in clinopyroxene (Camp et al. 1992).

It is recommended to launch exploration programs, both geological and geophysical, to search for peridot in the rest of the Saudi harrats. It is not known yet the reasons that the known occurrences of Saudi peridot are confined to the volcanic rocks of at the Harrat Kishb only. Detailed mineralogical, geochemical and isotopic studies are still needed to answer the questions arise. More chemical analyses are also needed for the Kishb peridot itself and the host basalt for better understanding of the ore genesis and petrogenesis as well.

Acknowledgement. The authors are very thankful for facilities and specimens presented by the Saudi Geological Survey. Prof. A.H. Ahmed is very thankful for the electron microprobe analyses.

\section{References}

1. T. F. Smith and M. S. Waterman, "Identification of common molecular subsequences," Journal of molecular biology, vol. 147, no. 1, pp. 195-197, 1981.

2. P. May, H.-C. Ehrlich, and T. Steinke, "Zib structure prediction pipeline: composing a complex biological workflow through web services," in Euro-Par 2006 Parallel Processing. Springer, 2006, pp. 1148-1158.

3. Foster and C. Kesselman, The Grid 2: Blueprint for a new computing infrastructure. Elsevier, 2003.

4. K. Czajkowski, S. Fitzgerald, I. Foster, and C. Kesselman, "Grid information services for distributed resource sharing," in High Performance Distributed Computing, 2001. Proceedings. 10th IEEE International Symposium on. IEEE, 2001, pp. 181-194.

5. Foster, C. Kesselman, J. Nick, and S. Tuecke, "The physiology of the grid: An open grid services architecture for distributed systems integration. 2002," Globus Project, 2004.

6. National Center for Biotechnology Information, Available: http://www.ncbi.nlm.nih.gov

7. Abdel Wahab, M. A. Abul Maaty, F. M. Stuart, H. Awad, and A. Kafafy, "The geology and geochronology of Al Wahbah maar crater, Harrat Kishb, Saudi Arabia," Quaternary Geochronology, vol. 21, pp. 70-76, 2014. 
8. H. Ahmed, A. M. Moghazi, M. R. Moufti, Y. H. Dawood, and K. A. Ali, "Nature of the lithospheric mantle beneath the Arabian Shield and genesis of Al spinel micropods: evidence from the mantle xenoliths of Harrat Kishb, Western Saudi Arabia,". Lithos, vol. 240-243, pp. 119-139, 2016.

9. G. F. Brown, R. O. Jackson, R. G. Bogue, and E. L., Jr. Elberg, "Geologic map of the northwestern Hijaz quadrangle, Kingdom of Saudi Arabia," U.S. Geological Survey Miscellaneous Geologic Investigations Map I204A, scale 1:500,000, 1963.

10. V. E. Camp, and M. J. Roobol, "Upwelling asthenosphere beneath western Arabia and its regional implications," Journal of Geophysical Research, vol. 97, pp. 15255-15271, 1992.

11. V. E. Camp, M. J. Roobol, and P. R. Hooper, "The Arabian continental alkali basalt province: Part III. Evolution of Harrat Kishb, Kingdom of Saudi Arabia," Geological Society of America Bulletin, vol. 104, pp. 379396, 1992.

12. R. G. Coleman, R. T. Gregory, and G. F. Brown, "Cenozoic volcanic rocks of Saudi Arabia," Ministry of Petroleum and Mineral Resources, Deputy Ministry for Mineral Resources, Jeddah, Kingdom of Saudi Arabia, 82 p., 1983.

13. P. Collenette, and D. J. and Grainger, "Mineral Resources of Saudi Arabia," Ministry of Petroleum and Mineral Resources Directorate General of Mineral Resources Jeddah, Kingdom of Saudi Arabia, 322 p., 1994.

14. Sh. Gao, R. L. Rudnick, W. -L. Xu, H. L. Yuan, Y. -S. Liu, R. J. Walker, I. S. Puchtel, X. Liu,, H. Huang, X. -R., Wang, and J. Yang, "Recycling deep cratonic lithosphere and generation of intraplate magmatism in the North China Craton," 9 p., 2008. Accessed in 11 May 2018 at:

http://www.mantleplumes.org/ RecycledLithosphere.html

15. Hadnott, B. L. Ehlmann, and B. L. Jolliff, "Mineralogy and chemistry of San Carlos high-alkali basalts: Analyses of alteration with application for Mars exploration," American Mineralogist, Vol. 102, pp. 284-301, 2017.

16. J. Hopp, M. Trieloff, and R. Altherr, "Neon isotopes in mantle rocks from the Red Sea region reveal large-scale plume-lithosphere interaction," Earth and Planetary Science Letters, vol. 219, pp. 61-76, 2004.

17. K. Konrad, D. W. Graham, C. R. Thornber, R. A. Duncan, A. J. R. Kent, and A. M. Al-Amri, "Asthenospherelithosphere interactions in Western Saudi Arabia: Inferences from ${ }^{3} \mathrm{He} /{ }^{4} \mathrm{He}$ in xenoliths and lava flows from Harrat Hutaymah," Lithos, vol. 248-251, pp. 339-352, 2016.

18. L. -C. Kuo, E. J. and Essene, "Petrology of spinel harzburgite xenoliths from the Kishb Plateau, Saudi Arabia," Contributions to Mineralogy and Petrology, vol. 93, pp. 335-346, 1986.

19. S. Lauretta, D. H. Hill, D. N. Della-Giustina, and M. Killgore, "The Fukang pallasite: evidence for nonequilibrium shock processing," The $3^{\text {th }}$ Annual Lunar and Planetary Science Conference (Extended Abstract), League City, March 13-17, No. 2250, 2006.

20. M. R. Moufti, A. M. Moghazi, and K. A. Ali, "Geochemistry and Sr-Nd-Pb isotopic composition of the Harrat Al-Madinah Volcanic Field, Saudi Arabia," Gondwana Research, vol. 21, pp. 670-689, 2012.

21. M. R. Moufti, K. Nemeth, N. El-Masry, and A. Qaddah, "Geoheritage values of one of the largest maar craters in the Arabian Peninsula: the Al Wahbah Crater and other volcanoes (Harrat Kishb, Saudi Arabia)," Central European Journal of Geosciences, vol. 5, pp. 254-271, 2013.

22. H. Murcia, J. M. Lindsay, S. Niedermann, S. J. Cronin, I. E. Smith, N. N. El-Masry, M. R. H. Moufti, K. Németh, "The potential use of cosmogenic nuclides for dating in Harrat Rahat," VORISA Scientific Meeting (Extended Abstract), Jeddah, Nov. 17-18, pp. 24-28, 2013.

23. J. H. Natland, "Why olivine control arguments cannot be used to infer high temperature at Samoa," http://www.mantleplumes.org/CoolSamoa.html

24. M. J. Roobol, and V. E. Camp, "Geological Map of the Cenozoic Lava Fields of Harrat Khaybar, Ithnayen and Kurs," Saudi Arabian Directorate General of Mineral Resources, Kingdom of Saudi Arabia, Geoscience Map (with text) GM-131, scale 1:250,000, 88 p.

25. E. Rubin, and C. Ma, "Meteoritic minerals and their origin," Chemie der Erde, vol. 77, pp. 325-385, 2017.

26. M. Sahl, and J. W. Smith, "Geology of the Al Muwayh Quadrangle Sheet 22E," Saudi Arabian Deputy Ministry for Mineral Resources, Kingdom of Saudi Arabia, Geoscience Map (with text) GM-88, 1:250,000 scale, 29 p., 1986.

27. S. I. Salf, and S. M. A. Shah, "Field and petrographic characteristics of Cenozoic basaltic rocks, Northwestern Saudi Arabia," Journal of African Earth Sciences, vol. 7, pp. 805-809, 1988. 
28. H. Shen, J. I. Koivula, and J. E. Shigley, "Identification of extraterrestrial peridot by trace elements," Gems and Gemology, Notes and New Techniques, Fall 2011, pp. 208-213, 2001.

29. J. E. Shigley, D. M. Dirlam, B. M. Laurs, E. W. Boehm, G. Bosshart, and W. F. Larson, "Gem localities of the 1990's," Gems and Gemology, vol. 36, pp. 292-335, 2000.

30. R. Thornber, "The petrology, geochemistry and origin of ultramafic inclusions and mafic alkaline magmas from Harrat Hutaymah, Saudi Arabia," Open-File Report USGS-OF-92-6, Saudi Arabian Ministry of Petroleum and Mineral resources, Deputy Ministry of Mineral Resources, Jeddah, Kingdom of Saudi Arabia, 244 p., 1992.

31. USGS, "An Overview of production of specific U.S. gemstones," U.S. Bureau of Mines Special Publication, 2016.

32. R. W. Wise, "Secrets of the gem trade, the connoisseur's guide to precious gemstones," Brunswick House Press, Massachusetts, 220 p., 2016. 